\title{
COMUNICACIÓN
}

\section{Fasciola hepatica infection in cattle and buffaloes in the State of Rio Grande do Sul, Brazil}

\author{
SANDRA MÁRCIA TIETZ MARQUES*, and MARIA LÚCIA SCROFERNEKER**
}

\begin{abstract}
We examined 482 livers, 377 from cattle and 105 from buffaloes slaughtered at a meat packing plant between April 1999 and November 1999, in Viamão, a town in the state of Rio Grande do Sul, in southern Brazil. The cattle slaughtered at the meat packing plant belonged to eleven towns: Cachoeira do Sul, Cachoeirinha, Capivari do Sul, Charqueadas, Encruzilhada do Sul, Ibiraiaras, Palmares do Sul, Pantâno Grande, Rio Pardo, Tupanciretã and Viamão. The buffaloes belonged to the following towns: Encruzilhada do Sul, Ibiraiaras, Parobé, Santo Antônio da Patrulha, and Uruguaiana. The occurrence rate of Fasciola hepatica was $10.34 \%$ for cattle in seven of the eleven towns included in the study (63.6\%) and $20 \%$ for buffaloes in four of the five towns (80\%). In terms of age, the occurrence rate was $81 \%$ for buffaloes with up to two years of life and $19 \%$ for buffaloes older than two years. The livestock from Cachoeira do Sul, Capivari do Sul, Ibiraiaras and Tupanciretã were not infected with bovine fascioliasis, and the buffaloes from Uruguaiana were not infected either. The studied areas may represent important endemic regions to fasciolosis, showing that zoonotic areas should be investigated.
\end{abstract}

Key words: Fasciola hepatica, ruminants, helminths, southern Brazil.

\section{INTRODUCTION}

Fasciolosis caused by the trematode Fasciola hepatica is a worldwide parasitic disease common in ruminants, especially cattle, buffaloes, sheep, goats, and swine. It may, however, affect humans ${ }^{1-6}$. Once ingested, parasites migrate through the liver parenchyma to reach the bile ducts. In ruminants, the liver is damaged and condemned, and the subclinical and chronic disease usually results in decreased production of meat, milk and wool, secondary bacterial infections, fertility problems, and great expenses with anthelmintics ${ }^{6-9}$. Chronic fasciolosis, confirmed by the inspection of rural properties and meat packing plants, and coprological examination of fecal material, was detected in the States of Rio Grande do Sul, Santa Catarina, Paraná, São Paulo, Rio de Janeiro and Minas Gerais; however, data on the geographic

* Veterinarian doctor and graduate student, Escola Agrotécnica Federal de Concórdia, EAFC, Concórdia, Santa Catarina, Brazil.

** Professor, Department of Microbiology, Institute of Basic Health Sciences, Universidade Federal do Rio Grande do Sul, Brazil.

Corresponding author:Dr. Maria Lúcia Scroferneker

Rua Vasco da Gama, 176/604 CEP 90040-111, Porto Alegre / RS - Brasil - fax: +55 5133163155

e-mail scrofern@vortex.ufrgs.br 
distribution and on the occurrence in the livers of animals are normally found to a moderate extent in the literature ${ }^{10,11,13}$.

A fasciolosis occurrence rate of $27.2 \%$ was found in the livers of animals slaughtered in 1978 in the state of Rio Grande do Sul, among 46,002 animals ${ }^{14}$. An occurrence rate higher than $90 \%$ of $F$. hepatica eggs among sheep and cattle was observed in the state of Rio Grande do Sul, in addition to losses of $12-13 \%$ due to noncompliance with the liver quality standards established by governmental authorities ${ }^{15}$. The occurrence rate of fasciolosis among 770 dairy cattle in the valley of Itajaí and in the coastal region of the state of Santa Catarina (including 19 municipalities, between September 1980 and September 1981 was analysed ${ }^{12}$. The occurrence rate was $100 \%$ in the analyzed municipalities, reaching $91.5 \%$ of 82 rural properties and $46 \%$ of the animals. The actions taken by the State Program for the Control of Bovine Fasciolosis were based upon the information provided by the Brazilian Meat Inspection System, whose headquarters are located in the grasslands of Rio Grande do Sul. The infection caused by $F$. hepatica is endemic, with condemnation of $52.14 \%$ (between 1982 and 1988) and 27.4\% (between 1989 and 1992) of the livers. The liver condemnation rate was never less than $30 \%$ in the last ten years. The condemnation rate in Brazilian endemic regions has been rising ${ }^{16}$. Between 1958 and 1963, the rates were $8 \%$, rising to $11.5 \%$ between 1974 and 1999 , and amounting to $14.7 \%$ in 1984 , with the condemnation of 14,298 infected livers ${ }^{16}$. Other authors carried out a retrospective study (1977-1988) on F. hepatica in cattle and buffaloes in 129 (64.8\%) municipalities of the state of Santa Catarina ${ }^{17}$. The presence of $F$. hepatica eggs was confirmed in $88(68.21 \%)$ municipalities, with a $27.86 \%$ occurrence rate for the cattle, and $24.72 \%$ for the buffaloes. The Federal Meat Inspection Service of the Ministry of Agriculture of Rio Grande do Sul registered a condemnation rate of $13.27 \%$ in 1992 due to $F$. hepatica ${ }^{11}$. The economic losses due to the condemnation of 250,000 fluke-infected livers cost U\$ 140,000,00, representing $15 \%$ of the livers inspected at official meat packing plants in the state of Rio Grande do Sul, and in infected properties approximately nine dollars are lost per animal due to reduced weaning weight at slaughter. A retrospective study about the condemnation of livers infected with the parasite, from May 1993 to May 1997, through the Federal Meat Inspection Service at meat packing plants in the southern region of Rio Grande do Sul, showed an occurrence rate of $13.2 \%{ }^{18}$. The analysis of 1,235 calves stools from 18 towns in the state of Rio Grande do Sul indicated the presence of $F$. hepatica eggs in $55.5 \%$ of the samples and a similar study in Curitiba, state of Paraná, showed an occurrence rate of $45 \%^{19}$. The present study aimed at assessing the occurrence rates for fasciolosis in cattle and buffaloes in different towns of the state of Rio Grande do Sul, regions that were not included in previous studies.

\section{MATERIALS AND METHODS}

This study was carried out at Líder meat packing plant, between April 1999 and November 1999, in Viamão, state of Rio Grande do Sul, southern Brazil. To determine the presence of $F$. hepatica, the bile ducts of 482 animals - 377 of cattle (Bos taurus) and 105 of buffaloes (Bubalus bubalis) - were dissected longitudinally. The slaughtered cattle belonged to the following towns: Cachoeira do Sul, Cachoeirinha, Capivari do Sul, Charqueadas, Encruzilhada do Sul, lbiraiaras, Palmares do Sul, Pantâno Grande, Rio Pardo, Tupanciretã and Viamão and the buffaloes belonged to the following towns: Encruzilhada do Sul, Ibiraiaras, Parobé, Santo Antônio da Patrulha, and Uruguaiana.

\section{RESULTS}

Among 377 livers of cattle, $(10.34 \%)$ were infected by $F$. hepatica, and animals of seven $(63.6 \%)$ towns presented fasciolosis. The livers belonging to animals from Cachoeira do Sul, Capivari do Sul, Ibiraiaras, and Tupanciretã, corresponding to $36.3 \%$, were not infected.

Of the 105 livers of buffaloes examined, 21 (20\%) were infected by $F$. hepatica, and four $(80 \%)$ towns presented infected animals. The livers belonging to buffaloes from Uruguaiana $(20 \%)$ were not infected. Flukes were found in 17 buffaloes $(81 \%)$ aged two years or less, and in four animals (19\%) older than two years.

\section{DISCUSSION}

Fasciolosis is usually observed in the southern 
and southeastern regions of Brazil, where it has an endemic nature. In these regions, the infection rate of dairy cattle ranges between 10 and $100 \%{ }^{13}$. The actions taken by the State Program for the Control of Bovine Fasciolosis were based upon the information provided by the Brazilian Meat Inspection System. In Rio Grande do Sul, the infection caused by $F$. hepatica is endemic, with condemnation of $52.14 \%$ (between 1982 and 1988) and 27.4\% (between 1989 and 1992) of the livers. Although our study was conducted in a smaller meat packing plant, the liver condemnation rate $(10.34 \%)$ was similar to the rate reported by authors for different regions of the country, showing poor reduction of fasciolosis.

Others authors observed a prevalence rate of $13.2 \%$ in cattle from Santa Vitória do Palmar, Cristal, Camaquã, Herval, Bagé, Dom Pedrito, São Lourenço, Rio Grande, Tapes, Hulha Negra, Pinheiro Machado, Canguçu, Encruzilhada do Sul, Caçapava do Sul, Candiota, Lavras, Amaral Ferrador and Cruz Alta ${ }^{18}$. The occurrence rate found in our study is similar to that reported by others, but in diferent area, which indicates the spread of this infection into other livestock-raising regions.

The state of Rio Grande do Sul contains 300400 thousand heads and 600 buffalo keepers, which corresponds to $1.3 \%$ of the cattle herd in the state. In Brazil, meat production is a primary goal and, in this case, parasitic diseases are a limiting factor; in spite of this, the presence of $F$. hepatica in buffaloes is not frequently studied $^{11,12}$. The analysis of random samples revealed an $81 \%$ occurrence rate for the infection in buffaloes aged less than two years, and 19\% in those older than two years. Parobé was the town with the highest rate, that is, $44.5 \%$ of the animals studied were infected, although the sample size was small. In Santo Antônio da Patrulha, $36.6 \%$ of the animals presented fasciolosis. In Ibiraiaras and Encruzilhada do Sul, respectively $10 \%$ and $4.3 \%$ of the animals were infected. The buffaloes belonging to Uruguaiana were not infected by $F$. hepatica. Others authors, reported a $10-15 \%$ prevalence rate in cattle in Encruzilhada do Sul, a town in the south of Rio Grande do Sul ${ }^{18}$, indicating the extension of this parasitic infection (with lower rates) to buffaloes raised therein. This study showed a mean of $20 \%$, which is in agreement with the data obtained by others ${ }^{17}$. Epidemiological studies on fasciolosis are of paramount importance in the state of Rio Grande do Sul, Brazil, so that zoonotic areas can be investigated. The studied areas may represent important endemic regions in cattle and buffaloes. In addition, it is necessary to study the epidemiology of the parasite in different regions in order to achieve a cost-effective control and obtain further information about the host, the parasite and its habitat.

\section{REFERENCES}

1.- RAMOS A M, ROMERO H Q, MOLINA C G, MARTINÉZ M H. Frecuencia de fascioliosis a traves de cuatro técnicas de diagnóstico en toros sacrificados en la plaza México. Vet Méx 1993; 24: 239-41.

2.- ACOSTA D. Epidemiología y control de Fasciola hepatica en el Uruguay. p. 233-256. In: Nari A. e Fiel C. Enfermedades parasitarias de importancia económica en bovinos -Bases para su prevención y control. Editorial Hemisferio Sur, Montevideo. 1994.

3.- CLAXTON J R, ZAMBRANO H, ORTIZ P et al. The Epidemiology of fasciolosis in the inter-Andrean valley of Cajamarca, Peru. Paras Intern 1997; 6: 281-8.

4.- WACKER K, ROFFEIS M,CONRANTHS F J. Cowcalf herds in East Germany: status quo of some parasite species and a comparison of chemoprophylaxis and pasture management in the control of gastrointestinal nematodes. Zentralbl. Veterinarmed 1999; 6: 475-83. (Abstract).

5.- ORTIZ P L, CLAXTON J R, CLARKSON M J et al. The specificity of antibody responses in cattle naturally exposed to Fasciola hepatica. Vet Parasitol 2000; 93: 121-34.

6.- ALCAÍNO H. Epidemiology of fascioliasis in Chile. In: R. Ehrlich, A. Nieto and L. Yarzabál. Basic Research in Helminthiasis. Ediciones Logos, Montevideo, Uruguay 1990. p. 11-30.

7.- OLAECHEA F V. Fasciola hepatica y Paramphistomum. Epidemiología y control de Fasciola hepatica en la Argentina. Cap 10, p. 213-232. In: Nari A., Fiel C., Editorial Hemisferio Sur, Montevideo 1989.

8.- EDDI C. Distomatosis: epidemiological and economic aspects of this zoonosis. Proceedings Symposium on the Epidemiology of Food-borne Parasitic Zoonoses. In: X Latin American Congress of Parasitology, I Uruguayan Congress of Parasitology. Montevideo, 1990. p. 50-9.

9.- DALTON J P. Fasciolosis. 1 Ed, Cabi Publishing, University Press, Cambridge, 1999 p. 113-49.

10.- SERRA-FREIRE N M. Fasciolose hepática. A Hora Veterinária 1995; ed extra 1: 13-8.

11.- SERRA-FREIRE $N$ M da, BORDIN E L, LESSA C S S et al. Reinvestigação sobre a distribuição da Fasciola hepatica no Brasil. A Hora Veterinária 1995; ed. extra 1: 19-21.

12.- BECK A A H. Fasciolose bovina. Boletim Técnico 33, Florianópolis, EMPASC, 1985. p18.

13.- SERRA-FREIRE N M.da. Se descuidar, a fascíola mata. 
A Granja 1995; 51: 28-31.

14.- SILVA I C, MÜLLER G, MATTOS M J T de, et al. Fasciolose. 1. Incidência e importância na bovino e ovinocultura do RS. Lavoura Arrozeira 1989; 33: 34-42.

15.- UENO H, GUTIERRES V C, MATTOS M J T, MÜLLER G. Fascioliasis problems in ruminants in Rio Grande do Sul, Brazil. Vet Parasit 1982; 11: 185-91.

16.- ECHEVARRIA F A M. Fasciolose-Ocorrência, Diagnóstico e Controle. Agroquímica Ciba-Geigy 1985; 27: 4-9.

17.- SERRA-FREIRE N M, NUERNBERG S. Dispersão geopolítica da ocorrência de Fasciola hepatica no Estado de Santa Catarina, Brasil. Mem. Inst Oswaldo Cruz, 87 (supl. I), 1992; p.263-9.
18.- MÜLLER G, JESUS L P de, PAUSEN R M M, SOUZA C A. Prevalência de fasciolose na região Sul do RS. Anais II Congr. Med. Vet., Gramado, 1997. p. 186 (Resumo).

19.- SANTOS A R dos, GOMES M J T M, CASTRO E S de, BASTOS C D. Ocorrência de Fasciola hepatica em bovinos da Grande Porto Alegre, RS, Brasil. Rev Bras Med Vet 1999; 21: 119-20.

20.- LUZ J E, FOCACCIA SICILIANO R, de OLIVEIRA A G, PISANI J C. Human fascioliasis in the metropolitan area of Curitiba, Brazil. Evaluation of the foci of infection and report of nine cases treated with Triclabendazole. Braz J Infect Dis 1999; 3: 220-5. (Abstract).

\title{
SOCHIPA
}

Sociedad Chilena de Parasitología

DE LO NATURALALO TECNOLÓGICO

VIII JORNADAS ANUALES

\author{
Auditorio Colegio Médico \\ Concepción
}

9 y 10 de enero 2004 